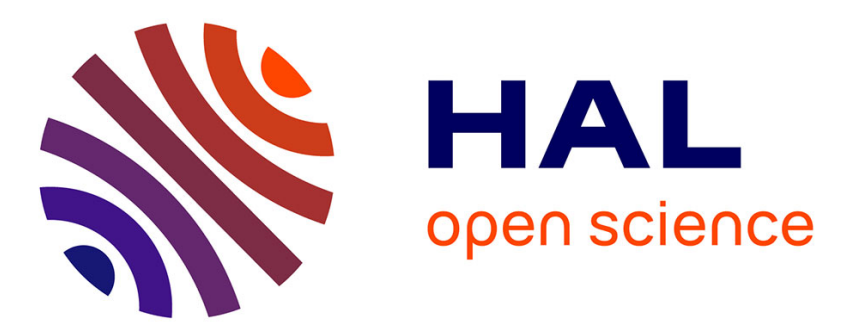

\title{
Liver X Receptor modulators: Effects on lipid metabolism and potential use in the treatment of atherosclerosis
}

C. Fiévet, B. Staels

\section{- To cite this version:}

C. Fiévet, B. Staels. Liver X Receptor modulators: Effects on lipid metabolism and potential use in the treatment of atherosclerosis. Biochemical Pharmacology, 2009, 77 (8), pp.1316. 10.1016/j.bcp.2008.11.026 . hal-00531848

\section{HAL Id: hal-00531848 \\ https://hal.science/hal-00531848}

Submitted on 4 Nov 2010

HAL is a multi-disciplinary open access archive for the deposit and dissemination of scientific research documents, whether they are published or not. The documents may come from teaching and research institutions in France or abroad, or from public or private research centers.
L'archive ouverte pluridisciplinaire HAL, est destinée au dépôt et à la diffusion de documents scientifiques de niveau recherche, publiés ou non, émanant des établissements d'enseignement et de recherche français ou étrangers, des laboratoires publics ou privés. 


\section{Accepted Manuscript}

Title: Liver X Receptor modulators: Effects on lipid metabolism and potential use in the treatment of atherosclerosis

Authors: C. Fiévet, B. Staels

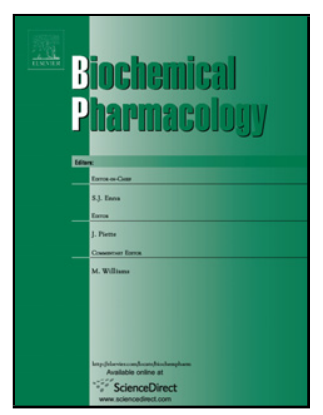

PII:

S0006-2952(08)00859-9

DOI: doi:10.1016/j.bcp.2008.11.026

Reference: BCP 10028

To appear in: $B C P$

Received date: 1-10-2008

Revised date: 24-11-2008

Accepted date: 25-11-2008

Please cite this article as: Fiévet C, Staels B, Liver X Receptor modulators: Effects on lipid metabolism and potential use in the treatment of atherosclerosis, Biochemical Pharmacology (2008), doi:10.1016/j.bcp.2008.11.026

This is a PDF file of an unedited manuscript that has been accepted for publication. As a service to our customers we are providing this early version of the manuscript. The manuscript will undergo copyediting, typesetting, and review of the resulting proof before it is published in its final form. Please note that during the production process errors may be discovered which could affect the content, and all legal disclaimers that apply to the journal pertain. 
Liver X Receptor modulators: effects on lipid metabolism and potential use in the treatment of atherosclerosis

C.Fiévet, B. Staels

Institut Pasteur de Lille, Lille, F-59019 France

Inserm, U545, Lille, F-59019 France

Université de Lille 2, Faculté des Sciences Pharmaceutiques et Biologiques et Faculté de Médecine, Lille, F-59006 France

$-1-$ 
Running title

LXR modulators and lipid metabolism in atherosclerosis

Corresponding Author

Bart STAELS, Inserm U545, Institut Pasteur, 1 rue du Professeur Calmette, 59045 Lille Cedex, France Bart.Staels@ pasteur-lille.fr

Keywords

LXRs, cholesterol homeostasis, liver steatosis, LXR ligands, atherosclerosis 
Abstract

Liver X Receptors (LXRs) are nuclear receptors that play a crucial role in regulating the expression of genes involved in lipid metabolism. Ligand activation of LXRs improves cholesterol homeostasis via multiple coordinated effects, and this function is likely to explain in part the protective effects of LXR activation on atherosclerosis reported in animal models. However, LXR activation may also induce undesirable side effects, such as lipogenesis and hypertriglyceridemia. This review discusses the potential to develop LXR modulators as therapeutic agents for atherosclerosis. 


\section{Introduction}

LXRs are members of the nuclear receptor superfamily comprising several ligand-activated transcription factors. LXRs regulate gene transcription by binding as heterodimers with the 9-cis retinoic acid receptor (RXR), an obligate partner, to specific DNA sequences known as LXR-responsive elements (LXREs) located in the promoters of target genes [1].

In the basal state and absence of ligand activation, the LXR/RXR heterodimer actively represses the transcription machinery of a number of target genes through interactions with corepressor complexes, such as the nuclear receptor corepressor (NcoR) and the related factor SMRT (silencing mediator of retinoic acid and thyroid hormone receptors), a concept supported by the enhanced basal expression of such LXR target genes in certain cells in the absence of receptor [2;3]. Binding of a ligand induces a conformational change in the protein, which leads to displacement of corepressors and results in the recruitment of coactivator proteins, such as steroid receptor coactivator (SRC)-1, Grip1 (a p160 family coactivator), or peroxisome-proliferator-activated receptor (PPAR) $\gamma$ coactivator $1 \alpha$ (PGC-1 $\alpha$ ). These events thereby promote the transcription of target genes [4].

Two LXR isotypes, LXR $\alpha$ and LXR $\beta$, have been identified. LXR $\alpha$ is highly expressed in liver, and at lower levels in the intestine, macrophages, adipose tissue, lung, adrenal glands and kidney, while LXR $\beta$ is ubiquitously expressed [5]. While LXR $\alpha$ and LXR $\beta$ are very similar in structure and exhibit a particular high degree of homology between their ligand-binding domains (LBDs), their nuclear retention and localization as well as function display some differences [6].

Both LXR isotypes are activated by physiological concentrations of oxidized derivatives of cholesterol (oxysterols) [7], as well as by cholesterol precursor sterols [8;9]. In addition, synthetic LXR ligands have been identified that are either pure agonists activating both LXR subtypes, or partial agonists exhibiting a LXR subtype-, tissue- and/or target gene-specificity. 
LXRs play a critical role in the control of lipid metabolism, acting as regulators of cholesterol and fatty acid metabolism, and have been the topic of several recent reviews [10]. LXRs function as cholesterol sensors and regulators of a set of genes associated with cholesterol absorption, transport, efflux and excretion, and as such control whole body cholesterol homeostasis. The activation of LXRs results in an improved reverse cholesterol transport and increased circulating high-density lipoprotein (HDL) levels. In addition, LXRs act as master regulators of hepatic lipid metabolism. Of importance, however, synthetic LXR agonists may induce lipogenesis, leading to increased plasma triglyceride concentrations and hepatic steatosis. Hence, considering the importance of dyslipidemia as a risk factor for atherosclerosis and subsequent cardiovascular diseases, activation of the LXR pathway as a potential target for therapeutic intervention in human cardiovascular disease may be questioned. However, it has also been shown that treatment with LXR agonists attenuate the development of atherosclerosis in mouse models [11-15], suggesting therefore that synthetic LXR agonists may be promising anti-atherosclerotic agents, despite a potentially adverse lipogenic effect. In this review, we discuss the therapeutic potential behind the development of LXR agonists, and the importance to identify novel therapeutic molecules that would act as selective LXR modulators, in order to obtain the desired cardioprotection and other benefits without causing liver fat accumulation.

\section{LXRs : sensors of lipid metabolism}

2.1. LXRs and cholesterol homeostasis

Although cholesterol is an essential component of cell membranes as well as the substrate for bile acid and steroid hormone synthesis, an excess of cellular cholesterol may be toxic and result in the development of atherosclerosis and subsequent cardiovascular diseases. A proper control of cholesterol homeostasis is therefore crucial. 
LXRs play an important role in controlling cholesterol homeostasis via their coordinated effects on 1) intestinal dietary cholesterol absorption, 2) liver cholesterol biosynthesis and uptake, 3) HDL particle synthesis and remodelling, conditioning their subsequent activity in reverse cholesterol transport, 4) cholesterol elimination from the body by regulating, at least in rodents, its conversion by the liver into bile acids and excretion of cholesterol into the bile.

\subsubsection{LXRs and dietary cholesterol absorption}

It has been reported that LXR $\alpha$ agonists inhibit intestinal cholesterol absorption in mice. It was initially hypothesized that this effect is due to an increase of the ATP-

binding cassette transporter (ABC) superfamily, subfamily A, member 1 (ABCA1) gene expression in the intestine [2]. However, since then, it has been demonstrated that ABCA1 is rather present on the basolateral membrane of enterocytes and, hence, does not mediate dietary cholesterol absorption but is rather involved in the generation of HDL

[16]. Two other ABC sterol transporters, ABCG5 and ABCG8, localized on the apical membrane of intestinal cells have been shown to be LXR target genes [17], but the direct role of these transporters in the decrease of cholesterol absorption upon LXR activation remains unclear.

Niemann-Pick C1 like 1 (NPC1L1) is a protein expressed in the brush border membrane of enterocytes in the small intestine and the molecular target of the cholesterol absorption inhibitor ezitimibe. NPC1L1 has been identified as an entero-transporter of dietary cholesterol [18]. A recent study performed in vitro, using a human enterocyte cell line, and in vivo in mice, has demonstrated that intestinal NPC1L1 expression is down-regulated by LXR [19]. All these data support a role of LXRs to decrease intestinal cholesterol absorption.

2.1.2. LXRs and liver cholesterol biosynthesis and uptake

One of the primary tissues in cholesterol metabolism is the liver, a key site of cholesterol biosynthesis and degradation. Moreover, the liver also acquires cholesterol of plasma low-density lipoproteins (LDL) via the LDL-receptor (LDLR). Intracellular cholesterol accumulation regulates both cholesterol biosynthesis and LDLR transcription 
through a negative feedback mechanism involving the inhibition of the sterol regulatory element-binding protein (SREBP) family of transcription factors implicated in the regulation of lipogenesis and cholesterol metabolism [20].

Using LXR-deficient mice fed a chow diet, it has been shown that LXR $\alpha$-deficiency increases the expression of the cholesterol synthesis regulator SREBP-2, which in turn activates genes involved in cholesterol synthesis, such as HMG-CoA synthase and reductase, the rate-limiting enzyme in cholesterol synthesis in liver, and of enzymes downstream of the mevalonate pathway, including farnesyl diphosphate synthase and squalene synthase [21]. Smaller increases in the hepatic expression of these genes, except SREBP-2, were also observed in LXR $\beta$-deficient mice [22]. However, very recent data suggest that LXR $\alpha$ can act as an inhibitor of cholesterol biosynthesis by directly silencing the expression of two cholesterogenic enzymes, the lanosterol 14 $\alpha$-demethylase (CYP51A1), and squalene synthase [23]. Finally, whereas no differences were seen in the regulation of LDLR gene expression in LXR $\alpha$-deficient mice under basal conditions [21], LXR $\alpha$ activation has been reported to induce expression of the LDLR gene in hepatoblastoma cells, in a SREBP-independent manner [24]. All together, these observations support evidence for an important role for LXR $\alpha$ in regulating cholesterol biosynthesis.

\subsubsection{LXRs and reverse cholesterol transport}

The reverse cholesterol transport (RCT) is a multi-step process by which there is net movement of cholesterol from peripheral tissues, such as macrophages, back to the liver via the plasma compartment. HDL acts as the acceptor and transport particle for effluxed cholesterol and as such occupies a central position in RCT. The first step of the RCT pathway consists in the uptake of cholesterol from cells by specific acceptors. ABCA1 is essential for this step since it initiates the formation of HDL by promoting the efflux of cholesterol and phospholipids to lipid-poor apolipoproteins (apo) such as apo A-I or apo E [25]. In the second step, the effluxed cholesterol is esterified by lecithin:cholesterolacyltransferase and moved to the centre of the HDL particle, transforming therefore nascent discoidal HDL particles into spherical HDL 3 particles. Next, 
upon the combined action of different enzymes involved in transfer of cholesterol, exchange of phospholipids and acquisition of apolipoproteins that are released during lipolysis of triglycerides in chylomicrons and very-low-density lipoproteins, HDL are remodelled into mature HDL and their cholesterol is taken up by the liver.

LXRs control the RCT by several potential mechanisms. Firstly, LXRs stimulate the mobilization of cholesterol from intracellular pools to the plasma membrane, hence enhancing the availability of cholesterol for efflux to extracellular acceptors [26;27]. Secondly, several apolipoproteins and lipid-modulating enzymes involved in cholesterol efflux and HDL remodeling are transcriptional targets for LXRs (Figure 1). Indeed, LXRs stimulate the expression of apoE in mouse macrophages and adipose tissue, but not in the liver [28], all genes of the apoC-I/apoC-IV/apoC-II gene cluster in human and murine macrophages [29] and apoA-IV in mouse liver and the human hepatoma HepG2 cell line [30]. Previous studies have demonstrated that LXR activation in cultured HepG2 cells or in vivo in mice, results in an increase of the expression and plasma activity of the enzyme catalyzing the exchange of phospholipids between HDL particles and triglyceride-rich lipoproteins, the phospholipid transfer protein (PLTP), leading therefore to an increased HDL-cholesterol level and HDL particle size [31;32]. LXRs activate human cholesterol ester transfer protein (CETP) gene expression [33]. CETP facilitates cholesterol ester and triglyceride transfer between HDL and apoB-containing lipoprotein particles. Ii is not expressed in rodents, but in humans, CETP activity is inversely correlated with HDL-cholesterol levels, and this observation raises the question whether LXR agonists will increase HDL-cholesterol in humans. Indeed, a previous onist treatment does

study showed that LXR agonist treatment does not increase HDL-cholesterol in human CETP transgenic mice [34]. Finally, the expression of lipoprotein lipase (LPL) which is the enzyme catalyzing the hydrolysis of lipoprotein triglycerides and which is involved in the maturation of HDL, is regulated by LXR [35]. This control is tissue-specific way, and LXR agonists induce expression of LPL in liver and macrophages, but not in adipose tissue [35]. Thirdly, LXRs enhance RCT via a direct action in macrophages (Figure 1). ABCA1 does not directly interact with mature HDL that constitutes the bulk of the plasma HDL, and therefore its activity does not readily account for cholesterol efflux from foam cells to HDL which represents the major atheroprotective mechanism for HDL. Two other members of the ABC superfamily, ABCG1 and ABCG4, have been demonstrated as mediators of cholesterol efflux from cells to HDL [36]. ABCG1 is highly expressed in macrophages (more than ABCG4) and its activity probably underlies the relationship between HDL levels and atherosclerotic risk. Using different strategies, such as ligand-activation of LXRs [2;36-38], analysis of cells that express a dominant- 
negative form of LXR $\alpha$ or LXR $\beta$ [39], peritoneal macrophages isolated from LXR $\alpha / \beta$-deficient mice [2;40], or small interfering (si)RNA [36], it has been demonstrated that the increase of ABCA1, ABCG4 and/or ABCG1 expression is LXR-dependent, and that both LXR isotypes are implicated. Moreover, in mice fed a low-fat diet, LXR $\alpha$ - and LXR $\beta$ - deficiency results in a significant accumulation of cholesterol in macrophages of the spleen, lung and arterial wall, concomitantly with a decreased hepatic ABCA1 gene expression [41]. Also, recent data demonstrate that pharmacological activation of LXRs in vivo promotes RCT from cholesterol injected-loaded macrophages accompanied by upregulation of ABCA1, ABCG1, ABCG5 and ABCG8 in liver and intestine [42].

\subsubsection{LXRs and bile acid metabolism}

Bile fluid contains water, cholesterol, phospholipids (mainly phosphatidylcholine), bile salts, bilirubin and bicarbonate ions. Bile acids are produced by the liver from cholesterol, and cholesterol $7 \alpha$-hydroxylase (CYP7A1) is the rate-limiting enzyme of the neutral pathways. Bile acids are then conjugated to glycine or taurine prior to secretion into bile. The biliary secretion of lipid and bile salts is controlled by hepatic cholesterol, phospholipids and bile salt transporters located on the hepatocyte canalicular membrane. The bile salt export pump is the major canalicular bile salt export pump in mammalian liver. The human multidrug resistant 3 p-glycoprotein, also known as ABCB4 (corresponding to the murine Mdr2 p-glycoprotein), translocates phosphatidylcholine molecules from the inner to the outer leaflet of the canalicular membrane. Finally, the functional complex ABCG5/G8 pumps cholesterol into bile. Cholesterol is only slightly soluble in aqueous solutions, but is made soluble in bile by bile salts and phospholipids, whose concentrations determine the degree of cholesterol saturation, corresponding to the cholesterol saturation index. Cholesterol gallstone disease, which accounts for nearly $80 \%$ of the gallstone diseases, results when disbalanced concentrations of cholesterol, phospholipids and bile salts in the bile provoke cholesterol crystal aggregation in gallbladder. During a meal, bile acids are released into the duodenum. The vast majority are subsequently reabsorbed throughout the intestine and return via the portal blood to the liver, where they exert a negative retrocontrol on bile acid synthesis. Recirculated bile acids are secreted again into bile after a meal. A fraction of bile acids escape intestinal absorption and are secreted in feces. This constitutes the main physiological way of cholesterol elimination from the body. The enterohepatic circulation and the feedback 
regulatory loop of bile acid synthesis as well as their excretion are essential mechanisms for the maintenance of cholesterol and bile acid homeostasis, preventing bile acid accumulation and avoiding therefore their toxicity as well as cholestasis. These different steps of bile acid metabolism are tightly controlled by a complementary and coordinated action of LXR and the Farnesoid X Receptor (FXR) which acts as the bile acid sensor [43].

In rodents, cholesterol accumulation in the liver induces a feed-forward activation of CYP7A1, which is mediated by LXR $\alpha$ [7]. Using LXR $\alpha$ - and LXR $\beta$-deficient mice, direct evidence for the role of LXR $\alpha$ in bile acid synthesis was provided [21], suggesting again a less important role of LXR $\beta$ in this effect [22]. Hepatic expression of ABCG5/G8 is increased upon LXR activation, and this results in an enhanced hepatobiliary excretion of cholesterol as well as an increased fecal neutral sterol excretion [44;45]. Thus the enterohepatic circulation and the regulatory feedback loop of bile acid synthesis as well as the excretion of their excess are essential mechanisms for the maintenance of cholesterol and bile acid homeostasis in which LXR play an important role. Interestingly, it has been demonstrated in vivo in mice that activation of LXRs prevents bile acid toxicity and cholestasis in female mice, which is associated with an increased expression of bile acid-detoxifying genes and a regulation of certain bile acid transporters [46]. Nevertheless, and despite this favourable effect of LXR, very recently, it has been shown that activation of LXR promotes cholesterol crystallisation [47]. This lithogenic effect of LXR is associated with dysregulation of hepatic transporters resulting in a combined effect of increased biliary concentrations of cholesterol and phospholipids and decreased biliary concentrations of bile salts, leading therefore to an increased cholesterol saturation index. However, the relevance of these anticholestatic and lithogenic effects of LXR to the human situation is not known. Indeed, it was demonstrated that in contrast to rodents, human CYP7A1 expression is not regulated by LXR in vitro in HepG2 cells [48]. Moreover, recently, it has been shown that LXR activation suppresses the expression of the enzyme in human primary hepatocytes [49]. Hence, it cannot be excluded that, in humans, LXR activation could potentially increase the risk of hepatic cholestasis.

2.2. LXRs and fatty acid metabolism

- 10 - 
Besides the role of LXRs in cholesterol homeostasis, LXR activation also increases the expression of genes of fatty acid biosynthesis (lipogenesis), and raises plasma triglyceride levels (hypertriglyceridemia) [50] [51] (Figure 2). This activity is demonstrated both using LXR-deficient mice, and/or pharmacological treatment of mice with a LXR agonist, in rodent as well as in human hepatocytes [49;52]. Moreover, activation of LXRs also promotes triglyceride accumulation in other cell types such as human skeletal muscle cells [53] or pancreatic $\beta$-cells (islets from diabetic rodent models or INS-1 insulinoma cells) [54].

Severe hepatic steatosis develops in mice upon LXR agonist treatment, and many studies explained this effect by a direct up-regulation of SREBP1c, the major SREBP1 isoform, in the liver which stimulates the transcription of lipogenic genes such as fatty acid synthase (FAS), acetyl-coA carboxylase (ACC) and stearoyl-coenzyme A desaturase 1 (SCD1) (a rate-limiting enzyme necessary for the biosynthesis of monounsaturated acids) [21;50;52;55;56]. In addition, some evidence indicates the ability of LXR to directly target expression of lipogenic genes, such as FAS [57], ACC [56], SCD1 [58] and the carbohydrate response element binding protein (ChREBP) [59] (a glucosesensitive transcription factor that promotes the hepatic conversion of carbohydrates into lipids). Finally, it has been shown that activation of LXR in vivo in mice results in the induction of the liver-specific uridine phosphorylase gene (L-UrdPase), an enzyme involved in the pathway of nucleotide biosynthesis and the regulation of plasma uridine levels, suggesting therefore a possible role for LXRs in the maintenance of uridine homeostasis [60]. Since $\beta$-alanine, a major product of uridine catabolism is a precursor of fatty acid synthesis, and although no evidence for a direct regulatory pathway of L-UrdPase gene regulation by LXRs has yet been provided, it is possible that LXR regulation of this gene participates in the mechanism of LXR-induction of lipogenesis.

Apart from the induction of hepatic steatosis, it has been reported that pharmacological LXR activation in mice results in elevated plasma triglycerides [50] and promotes pathways of very low density lipoprotein-triglyceride secretion [51]. Despite the fact that the mechanisms are not well understood, studies have uncovered several important proteins that could mediate the LXR-mediated hypertriglyceridemic effect. These include SREBP-1c and angiopoietin-like protein 3 (Angptl3) [61] (a liver-secreted protein that increases both plasma triglycerides by inhibiting LPL activity in different tissues, and free fatty acids by activating lipolysis in adipocytes) whose expression is increased, and/or apoA-V which is down-regulated by LXR activation [62].

-11 - 
Despite the fact that LXR activation leads to severe lipid overloading in non-adipose tissues, severe hepatic steatosis and accumulation of lipid in muscle cells, conditions usually associated with insulin resistance and type 2 diabetes, this does not result in any apparent deleterious effect on hepatic insulin sensitivity [63] or insulin action [53]. However, the long-term consequences of triglyceride accumulation upon LXR activation in muscle have yet to be evaluated. On the other hand, it has been shown that, upon chronic activation by LXR agonists, lipid overloading in pancreatic $\beta$-cells causes serious $\beta$-cell dysfunction and apoptosis, a significant process in the development of type 2 diabetes [54].

LXR-induced lipogenesis hampers the development of LXR agonists as novel therapeutics, and a thorough knowledge on the different roles that the two LXR subtypes play in this process is crucial for the design of improved selective molecules. Previous studies show that in vivo in mice, both LXR $\alpha$ and LXR $\beta$ isoforms are implicated in the fatty acid synthesis pathway [50;55], with a more prominent implication of LXR $\alpha$ [21;22]. However, other reports suggest that the LXR $\beta$ isoform may be the more important isoform for lipogenesis and plasma triglyceride metabolism up-regulation [41].

\subsection{Factors determining the transcriptional activity of LXRs}

Tissue-specific regulation of certain genes by LXRs exists, exemplified by the regulation of the apoE gene in adipose tissue and macrophages but not in liver [28], or the induction of LPL only in liver and macrophages but not in adipose tissue [35]. Although the precise molecular basis for this regulation is unknown, several mechanisms could contribute to this specificity. The first and more evident factor that determines the transcriptional selectivity of the LXR isotypes is their respective tissue distribution. Indeed, since LXR $\alpha$ is expressed in liver to a higher extent than LXR $\beta$ [5], it appears that the undesirable stimulation of lipogenesis by LXR ligands may be primarily mediated

by LXR $\alpha$. A second factor determining cellular transcriptional specificity of LXRs relates to the concept of Selective LXR Modulator (SLXRM). Indeed, differential regulation 
of LXR target genes due to distinct corepressor recruitment has been described. For example, the SREBP1c and the ABCA1 genes exhibit a striking difference in the way LXRs regulate their promoter activity [3]. While the absence of LXRs in mice causes derepression of basal ABCA1 expression in macrophages and the intestine, this derepressive effect does not occur on the SREBP1c promoter. This is thought to result from a differential recruitment of the corepressors NcoR and SMRT to the ABCA1 but not the SREBP1c promoters. Moreover, differences in intracellular levels of coactivators and corepressors between different cells occur that could result in certain target cell-specific LXR responses [64]. Also, certain cofactors, such as receptor interacting protein (RIP) 140, can act in liver either as coactivator or corepressor, depending upon the LXR target genes [65].

\section{LXR ligands : approaches for the development as therapeutic agents}

The identification of high-affinity synthetic agonists for nuclear receptors has enabled many studies on the biological functions of these nuclear receptors. The availability of antagonists has also been important to demonstrate that a given effect is indeed mediated by a nuclear receptor. However, the development of pure agonists and antagonists are only rarely the goal in therapeutic strategies based on nuclear receptors as drug targets, when attempting to improve the pharmacological profile of new molecules. In most cases, partial and selective modulators (agonists or antagonists) are desired, which activate or block the receptor in a tissue-specific manner and/or present target-gene specificity. The prototypic examples for such selective nuclear receptor modulators are tamoxifen and raloxifen which are selective estrogen receptor (ER) modulators (SERMs). These drugs activate or inhibit the ER, therefore enabling estrogen-like stimulation in brain, bone and potentially the cardiovascular system, while inhibiting the responses to estrogen in breast and prostate.

3.1 LXR activators 
While cholesterol itself has no effect on LXR activity, oxidized cholesterol derivatives (oxysterols) activate LXRs, with the most potent activators being the naturally occurring 22(R)-hydroxycholesterol, 20(S)-hydroxycholesterol, 24(S),25-epoxycholesterol, and 27-hydroxycholesterol [7;66;67]. Importantly, these oxysterols elicit a LXR response at concentrations consistent with those found in tissue extracts [7;68]. Moreover, it has been argued that certain oxysterols, such as 27-hydroxycholesterol or the synthetic oxysterol $N, N$-dimethyl-3 $\beta$-hydroxycholenamide, may be cell-specific physiological LXR ligands [69;70], and recently it has been shown that oxysterols may present LXR target-gene specificity in vivo [71].

Most of the endogenous LXR ligands identified so far activate both LXR $\alpha$ and LXR $\beta$. However, the oxysterol 5,6-24(S),25-diepoxycholesterol is a relatively selective LXR $\alpha$ ligand, suggesting the feasibility of developing subtype-selective LXR ligands for pharmacological applications [68]. In addition, natural and synthetic 6 $\alpha$-hydroxy bile acids are more selective activators of LXR $\alpha$ than LXR $\beta$ [72]. Moreover, cholestenoic acid, a metabolite of 27-hydroxycholesterol, is a naturally occurring ligand for LXR $\alpha$, but not for LXR $\beta$ [73].

In addition to endogenous ligands, a number of synthetic LXR ligands have been developed. Most of them are dual agonists, activating both LXR $\alpha$ and LXR $\beta$, and present both the favourable effects on cholesterol metabolism and the unfavourable effects on fatty acid metabolism. Treating mice deficient in either LXR $\alpha$, LXR $\beta$ or both, with an agonist displaying equal potency for both isoforms or an agonist selective for LXR $\alpha$, demonstrated that specific activation of LXR $\alpha$ or LXR $\beta$ yields distinctive lipid outcomes in vivo [74]. Most importantly, this study lends further support to the hypothesis that a specific agonist of LXR $\beta$ would raise plasma HDL-cholesterol levels and increase the expression of ABCA1 in macrophages (stimulating therefore cholesterol efflux), without causing liver triglyceride accumulation. This particular interest for LXR $\beta$ has been supported by another study in which selective activation of this isotype by treatment of LXR $\alpha$-deficient mice with a dual agonist results in a strongly decreased expression of hepatic genes concomitant with an increased expression of both the ABCA1 and SREBP1c genes in peripheral tissues (kidney and duodenum), causing plasma

HDL increases without hypertriglyceridemia [75]. 
The nonsteroidal compounds T0901317, [N-(2,2,2-trifluoro-ethyl)-N-[4-(2,2,2-trifluoro-1-hydroxy-1-trifluoromethyl-ethyl)-phenyl]-benzenesulfonamide] (Tularik Inc.) [50] and GW3965, [3-(3-(2-chloro-3-trifluoromethyl-benzyl-2,2-diphenyl-ethylamino)propoxy) phenylacetic acid] (GlaxoSmithKline Pharmaceuticals) [76] are structurally distinct and present some differences in their biological activity. In cell-based studies, GW3965 is a relatively weak activator of LXRs compared to T0901317, and this is particularly pronounced for LXR $\alpha$ in human hepatoma cells. While in vivo, in mice, both compounds generally increase rate of RCT and improve cholesterol homeostasis, their effects on fatty acid metabolism are different (Table 1). Moreover, in vivo, in mice, GW3965 behaves as a selective modulator of LXR $\alpha$ activity in liver [77]. Indeed, whereas both T0901317 and GW3965 induce ABCA1 expression to similar extents in the small intestine, in liver, T0901317 significantly induces FAS and ABCA1 whereas GW3965 has limited effects. These observations are reflected by increased HDL-cholesterol levels in mice treated with T0901317 or GW3965, whereas the induction of steatosis occurs only in mice treated with T0901317. This tissue-specific induction by GW3965 of intestinal rather than hepatic LXR genes was confirmed in mice with liveror intestinal-specific deletion of the Abcal gene [78]. Different patterns of coactivator recruitment between T0901317 and GW3965 may account for their tissue selectivity [77]. However, it is not so clear whether GW3965 can be defined as a tissue-specific LXR agonist regulating non-hepatic genes and improving cholesterol metabolism while avoiding deleterious lipogenic effects, since data from other in vivo studies evidenced an increased hepatic triglyceride content and/or an hypertriglyceridemia after treatment with this compound $[11 ; 63 ; 70]$.

The discovery of the crucial role that LXRs play in cholesterol metabolism has resulted in an interest to design novel chemical entities acting as LXR ligands for potential therapeutic intervention in atherosclerosis, particularly as HDL inducers. Structure-activity relationship (SAR) studies have been therefore conducted, resulting in the synthesis of different LXR agonists. Among them are acetyl-podocarpic acid and derivatives [79;80], 2-aryl-N-acyl indole [81], or N-acylthiadiazolines [82], anilinohexafluoroisopropanols [83], phenyl acetic acid substituted quinolines [12], acanthoic acid-related diterpenes [84], acidic heterocycles [85]. However, although most of these compounds are active on cholesterol metabolism, they also undesirably upregulate SREBP1-c gene expression, limiting therefore their development. Interestingly, two synthetic steroidal LXR agonists, ATI-829, [3 $\alpha, 6 \alpha, 24$-trihydroxy-24, 24-di(trifluromethyl)-5 $\beta$-cholane] (Anagen Therapeutics Inc.) [13] and DMHCA, [N,N-dimethyl-3 $\beta$ - 
hydroxy-cholenamide] [14;70] have been reported as good candidates for drug development by selectively activating in mice LXR target genes in certain tissues but not genes involved in liver lipogenesis. Finally, Riccardin C (RC), a non-sterol natural liverwort-derived product, has been identified as a LXR $\alpha$ agonist/LXR $\beta$ antagonist [86]. In THP-1 cells, RC binds directly to LXR $\alpha$ and recruits the coactivator SRC-1, leading therefore to the activation of LXR $\alpha$-dependent reporter genes. RC also possesses the ability to bind LXR $\beta$ but its inability to recruit coactivators results in the failure of LXR $\beta$-mediated transactivation. RC induces ABCA1 and ABCG1 expression, resulting in an enhanced cholesterol efflux, and increases SREBP1c mRNA level in THP-1 cells while the compound has no effect on SREBP1-c and ABCG1 expression in HepG2 cells. Although studies are required to elucidate the precise mechanisms of RC's selective actions, these data suggest that LXR modulators which do not upregulate hepatic lipogenic genes may lead to improved therapeutic strategies.

3.2 LXR antagonists

Geranylgeranyl-PP, a major product of farnesyl-PP which represents a key branch in the mevalonic pathway for the cholesterol synthesis, negatively regulates LXR $\alpha$ and LXR $\beta$ transcriptional activity by interfering with LXR-coactivator interaction [67]. Unsaturated fatty acids have been demonstrated to inhibit LXR activation of SREBP1-c by antagonizing ligand-dependent activation of LXR [87] or inhibiting LXR binding to a LXRE [88]. Finally, plasma from hypercholesterolemic patients contains elevated concentrations of oxidized cholesterol 3-sulfates that could act as natural antagonists of LXR $\alpha$ and LXR $\beta$ [89].

Recently, it has been reported that methanol extracts from plants used in oriental medicine present in vitro selective LXR $\alpha$ inhibitory activity with insignificant effects on LXR $\beta$ activity [90]. Two of these extracts, MEH184 and MEH185 suppress the transcriptional activity of LXR $\alpha$ as well as the expression of LXR $\alpha$ target genes, exerting repressive effects on 3T3-L1 adipocyte differentiation and triglyceride accumulation without significant changes in cellular cholesterol level.

- 16 - 


\section{LXR ligands : promises for atherosclerosis treatment}

Intervention studies in murine models support the hypothesis that drugs which target LXRs may offer benefits in the treatment of atherosclerosis. Indeed, administration of LXR ligands to apoE- or LDR-deficient mice clearly demonstrated that LXR activation results in a significant reduction of atherosclerosis [11-15]. Moreover, results from bone marrow transplantation experiments showed that loss of LXR function in macrophages resulted in an increased lesion formation in apoE-deficient [91] or LDLR-deficient mice [92]. Importantly, recent results demonstrate that treatment of mice lacking both apoE and LXR $\alpha$ with a synthetic LXR ligand ameliorates cholesterol homeostasis and reduces atherosclerosis, providing therefore evidence for the ability of LXR $\beta$ to compensate for the loss of LXR $\alpha$ [93]. These data provide support for further selective targeting of LXR $\beta$ to identify drugs for the treatment of atherosclerosis. The anti-atherogenic effect of LXRs can be mediated by metabolic regulation, e.g. an increased HDL formation and an improved macrophage cholesterol metabolism, but also by a direct protective action on the artery wall via inhibition of inflammatory responses, particularly in macrophages [92]. This anti-inflammatory action of LXR activation appears to be mediated through repression of nuclear factor- $\mathrm{B}$ (NF- $\mathrm{B})$ signalling and subsequent inhibition of the expression of target genes of NF- $\mathrm{B}$, such as interleukin-6 or matrix metalloproteinase-9 [94]. LXR ligands repress these genes in macrophages derived from wild-type, LXR $\alpha$ - or LXR $\beta$-deficient mice but are unable to do so in macrophages from LXR $\alpha / \beta$-deficient mice, indicating that both LXR isoforms possess anti-inflammatory activities. Moreover, subsequent work has suggested that tissue factor and osteopontin, both inflammatory response genes associated with an increased risk for developing atherosclerosis, are subject to similar repression by LXR ligands in macrophages [95;96]. Recently, it has been demonstrated that 48-hour pretreatment with LXR agonists leads to an increase in Toll-like receptor (TLR)-4 expression in human macrophages, resulting in an enhanced responsiveness of macrophages to lipopolysaccharide (LPS) (a chief pathogen-associated molecular pattern from Gram-negative bacteria), and an increased secretion of cytokines that activate an immune adaptive inflammatory response [97]. In addition, through enhancement of NADPH oxidase subunit expression, LPS-activated macrophages produce toxic reactive oxygen species (ROS), which could directly kill bacteria [97]. Thus, all these data identify a novel role for LXR in the preparation of macrophages to exert antibacterial activities.

- 17 - 
Progression of immune response is also regulated at the level of macrophage survival. It has been shown that upregulation of the apoptosis inhibitory factor (AIM), also called Spa or Api6, in mouse lesion macrophages in response to specific activation of the LXR $\alpha$ isoform facilitates macrophage survival against different apoptosisinducing stimuli such as bacterial pathogens [98;99]. This macrophage survival pathway is very important in atherogenesis since it participates in foam cell formation, a characteristic of the early atherosclerotic lesion. Interestingly, AIM deficiency results in a protection from atherosclerosis [98]. It can be hypothesized that the anti-apoptotic effects of AIM contrasts with the other LXR/RXR-dependent gene effects that are atheroprotective, such as the critical role of LXR in cholesterol efflux from macrophages. Indeed, an uncontrolled lipid accumulation in LXR-deficient macrophages increases atherosclerosis susceptibility, despite the increased rate of macrophage apoptosis. However, inducing macrophage apoptosis may contribute to the development of the lesion necrotic lipid core, thus potentially leading to the destabilization of the atherosclerotic plaque. The anti-apoptotic effect of LXR-induced AIM could be therefore beneficial for atherosclerotic complications. Moreover, loss of macrophages might promote a proatherogenic environment, due to, for example, decreased production of apoE and reduced scavenging of toxic substances such as oxidized LDL. The relevance of the role of LXR $\alpha$ signalling on the macrophage survival pathway for human macrophages remains to be studied.

\section{Conclusion and perspectives}

In conclusion, as a transcriptional regulator of genes implicated in RCT and hepatic cholesterol catabolism, both LXR $\alpha$ and LXR $\beta$ have emerged as attractive targets to design new drugs in the field of cardiovascular disease. However, beside these desirable pharmacologic effects, undesirable effects such as an increased hepatic lipogenesis, currently hamper the development of LXR agonists. LXR $\alpha$ is the dominant isoform involved in the control of hepatic lipogenesis, and some data argue in favour of a preferential selective LXR $\beta$ activation as a mean to limit LXR-induced lipogenesis in liver. Importantly, it appears that both isoforms are implicated in the favourable effects of LXR on cholesterol homeostasis, and this fact may provide justification for further selective targeting of LXR $\beta$. This may be accomplished through isotype-selective agonists or 
gene- or tissue-specific agonists, such as selective LXR modulators, or through the development of LXR antagonists which would specifically repress lipogenic gene expression in liver. Finally, while LXR ligands represent attractive therapeutic agents for atherosclerosis, it has to be noted, firstly, that none have been tested sofar in humans, and secondly, that the basis for examination of their use in humans has to take into account the existence of important species-differences with respect to the genes regulated by LXR. 
Acknowledgments

This work was supported by the Institut National de la Santé et de la Recherche Scientifique, the Fondation Cœur et Artères, Région Nord Pas de Calais/FEDER and the FP7 European Collaborative project entitled « Targeting OBesity-driver Inflammation » (TOBI) (grant agreement $\left.n^{\circ} 201608\right)$. 


\section{References}

1. Willy PJ, Umesono K, Ong ES, Evans RM, Heyman RA, Mangelsdorf DJ. LXR, a nuclear receptor that defines a distinct retinoid response pathway. Genes Dev. 1995; 9(9):1033-45.

2. Repa JJ, Turley SD, Lobaccaro JA, Medina J, Li L, Lustig K et al. Regulation of absorption and ABC1-mediated efflux of cholesterol by RXR heterodimers. Science 2000; 289(5484):1524-9.

3. Wagner BL, Valledor AF, Shao G, Daige CL, Bischoff ED, Petrowski M et al. Promoter-specific roles for liver X receptor/corepressor complexes in the regulation of ABCA1 and SREBP1 gene expression. Mol. Cell Biol. 2003; 23(16):5780-9.

4. Glass CK, Rosenfeld MG. The coregulator exchange in transcriptional functions of nuclear receptors. Genes Dev. 2000; 14(2):121-41.

5. Repa JJ, Mangelsdorf DJ. The role of orphan nuclear receptors in the regulation of cholesterol homeostasis. Annu. Rev. Cell Dev. Biol. 2000; 16:459-81.:459-81.

6. Prufer K, Boudreaux J. Nuclear localization of liver X receptor alpha and beta is differentially regulated. J. Cell Biochem. 2007; 100(1):69-85.

7. Lehmann JM, Kliewer SA, Moore LB, Smith-Oliver TA, Oliver BB, Su JL et al. Activation of the nuclear receptor LXR by oxysterols defines a new hormone response pathway. J. Biol. Chem. 1997; 272(6):3137-40.

8. Yang C, McDonald JG, Patel A, Zhang Y, Umetani M, Xu F et al. Sterol intermediates from cholesterol biosynthetic pathway as liver X receptor ligands. J. Biol. Chem. 2006; 281(38):27816-26.

9. Heverin M, Meaney S, Brafman A, Shafir M, Olin M, Shafaati M et al. Studies on the cholesterol-free mouse: strong activation of LXR-regulated hepatic genes when replacing cholesterol with desmosterol. Arterioscler. Thromb. Vasc. Biol. 2007; 27(10):2191-7.

10. Nomiyama T, Bruemmer D. Liver X receptors as therapeutic targets in metabolism and atherosclerosis. Curr. Atheroscler. Rep. 2008; 10(1):88-95.

11. Joseph SB, McKilligin E, Pei L, Watson MA, Collins AR, Laffitte BA et al. Synthetic LXR ligand inhibits the development of atherosclerosis in mice. Proc. Natl. Acad. Sci. U. S. A. 2002; 99(11):7604-9.

12. Hu B, Collini M, Unwalla R, Miller C, Singhaus R, Quinet E et al. Discovery of phenyl acetic acid substituted quinolines as novel liver X receptor agonists for the treatment of atherosclerosis. J. Med. Chem. 2006; 49(21):6151-4. 
13. Peng D, Hiipakka RA, Dai Q, Guo J, Reardon CA, Getz GS et al. Antiatherosclerotic effects of a novel synthetic tissue-selective steroidal liver X receptor agonist in lowdensity lipoprotein receptor-deficient mice. J. Pharmacol. Exp. Ther. 2008; 327(2):332-42.

14. Kratzer A, Buchebner M, Pfeifer T, Becker TM, Uray G, Miyazaki M et al. Synthetic LXR agonist attenuates plaque formation in apoE-deficient mice without inducing liver steatosis and hypertriglyceridemia. J. Lipid Res. 2008;

15. Terasaka N, Hiroshima A, Koieyama T, Ubukata N, Morikawa Y, Nakai D et al. T-0901317, a synthetic liver X receptor ligand, inhibits development of atherosclerosis in LDL receptor-deficient mice. FEBS Lett. 2003; 536(1-3):6-11.

16. Brunham LR, Kruit JK, Iqbal J, Fievet C, Timmins JM, Pape TD et al. Intestinal ABCA1 directly contributes to HDL biogenesis in vivo. J. Clin. Invest. 2006; 116(4):1052-62.

17. Repa JJ, Berge KE, Pomajzl C, Richardson JA, Hobbs H, Mangelsdorf DJ. Regulation of ATP-binding cassette sterol transporters ABCG5 and ABCG8 by the liver X receptors alpha and beta. J. Biol. Chem. 2002; 277(21):18793-800.

18. Altmann SW, Davis HR, Jr., Zhu LJ, Yao X, Hoos LM, Tetzloff G et al. Niemann-Pick C1 Like 1 protein is critical for intestinal cholesterol absorption. Science 2004; 303(5661):1201-4.

19. Duval C, Touche V, Tailleux A, Fruchart JC, Fievet C, Clavey V et al. Niemann-Pick C1 like 1 gene expression is down-regulated by LXR activators in the intestine. Biochem. Biophys. Res. Commun. 2006; 340(4):1259-63.

20. Brown MS, Goldstein JL. A receptor-mediated pathway for cholesterol homeostasis. Science 1986; 232(4746):34-47.

21. Peet DJ, Turley SD, Ma W, Janowski BA, Lobaccaro JM, Hammer RE et al. Cholesterol and bile acid metabolism are impaired in mice lacking the nuclear oxysterol receptor LXR alpha. Cell 1998; 93(5):693-704.

22. Alberti S, Schuster G, Parini P, Feltkamp D, Diczfalusy U, Rudling M et al. Hepatic cholesterol metabolism and resistance to dietary cholesterol in LXRbeta-deficient mice. J. Clin. Invest. 2001; 107(5):565-73.

23. Wang Y, Rogers PM, Su C, Varga G, Stayrook KR, Burris TP. Regulation of Cholesterologenesis by the Oxysterol Receptor, LXR \{alpha\}. J. Biol. Chem. 2008; 283(39):26332-9.

24. Ishimoto K, Tachibana K, Sumitomo M, Omote S, Hanano I, Yamasaki D et al. Identification of human low-density lipoprotein receptor as a novel target gene regulated by liver X receptor alpha. FEBS Lett. 2006; 580(20):4929-33. 
25. Francis GA, Knopp RH, Oram JF. Defective removal of cellular cholesterol and phospholipids by apolipoprotein A-I in Tangier Disease. J. Clin. Invest. 1995; 96(1):7887.

26. Wang N, Ranalletta M, Matsuura F, Peng F, Tall AR. LXR-induced redistribution of ABCG1 to plasma membrane in macrophages enhances cholesterol mass efflux to HDL. Arterioscler. Thromb. Vasc. Biol. 2006; 26(6):1310-6.

27. Rigamonti E, Helin L, Lestavel S, Mutka AL, Lepore M, Fontaine C et al. Liver X receptor activation controls intracellular cholesterol trafficking and esterification in human macrophages. Circ. Res. 2005; 97(7):682-9.

28. Laffitte BA, Repa JJ, Joseph SB, Wilpitz DC, Kast HR, Mangelsdorf DJ et al. LXRs control lipid-inducible expression of the apolipoprotein E gene in macrophages and adipocytes. Proc. Natl. Acad. Sci. U. S. A. 2001; 98(2):507-12.

29. Mak PA, Laffitte BA, Desrumaux C, Joseph SB, Curtiss LK, Mangelsdorf DJ et al. Regulated expression of the apolipoprotein E/C-I/C-IV/C-II gene cluster in murine and human macrophages. A critical role for nuclear liver X receptors alpha and beta. J. Biol. Chem. 2002; 277(35):31900-8.

30. Liang Y, Jiang XC, Liu R, Liang G, Beyer TP, Gao H et al. Liver X receptors (LXRs) regulate apolipoprotein AIV-implications of the antiatherosclerotic effect of LXR agonists. Mol. Endocrinol. 2004; 18(8):2000-10.

31. Laffitte BA, Joseph SB, Chen M, Castrillo A, Repa J, Wilpitz D et al. The phospholipid transfer protein gene is a liver X receptor target expressed by macrophages in atherosclerotic lesions. Mol. Cell Biol. 2003; 23(6):2182-91.

32. Cao G, Beyer TP, Yang XP, Schmidt RJ, Zhang Y, Bensch WR et al. Phospholipid transfer protein is regulated by liver X receptors in vivo. J. Biol. Chem. 2002; 277(42):39561-5.

33. Luo Y, Tall AR. Sterol upregulation of human CETP expression in vitro and in transgenic mice by an LXR element. J. Clin. Invest. 2000; 105(4):513-20.

34. Masson D, Staels B, Gautier T, Desrumaux C, Athias A, Le Guern N et al. Cholesteryl ester transfer protein modulates the effect of liver X receptor agonists on cholesterol transport and excretion in the mouse. J. Lipid Res. 2004; 45(3):543-50.

35. Zhang Y, Repa JJ, Gauthier K, Mangelsdorf DJ. Regulation of lipoprotein lipase by the oxysterol receptors, LXRalpha and LXRbeta. J. Biol. Chem. 2001; 276(46):43018-24.

36. Wang N, Lan D, Chen W, Matsuura F, Tall AR. ATP-binding cassette transporters G1 and G4 mediate cellular cholesterol efflux to high-density lipoproteins. Proc. Natl. Acad. Sci. U. S. A. 2004; 101(26):9774-9. 
37. Costet P, Luo Y, Wang N, Tall AR. Sterol-dependent transactivation of the ABC1 promoter by the liver X receptor/retinoid X receptor. J. Biol. Chem. 2000; 275(36):28240-5.

38. Engel T, Lorkowski S, Lueken A, Rust S, Schluter B, Berger G et al. The human ABCG4 gene is regulated by oxysterols and retinoids in monocyte-derived macrophages. Biochem. Biophys. Res. Commun. 2001; 288(2):483-8.

39. Venkateswaran A, Laffitte BA, Joseph SB, Mak PA, Wilpitz DC, Edwards PA et al. Control of cellular cholesterol efflux by the nuclear oxysterol receptor LXR alpha. Proc. Natl. Acad. Sci. U. S. A. 2000; 97(22):12097-102.

40. Claudel T, Leibowitz MD, Fievet C, Tailleux A, Wagner B, Repa JJ et al. Reduction of atherosclerosis in apolipoprotein E knockout mice by activation of the retinoid X receptor. Proc. Natl. Acad. Sci. U. S. A 2001; 98(5):2610-5.

41. Schuster GU, Parini P, Wang L, Alberti S, Steffensen KR, Hansson GK et al. Accumulation of foam cells in liver X receptor-deficient mice. Circulation 2002; 106(9):1147-53.

42. Naik SU, Wang X, Da Silva JS, Jaye M, Macphee CH, Reilly MP et al. Pharmacological activation of liver X receptors promotes reverse cholesterol transport in vivo. Circulation 2006; 113(1):90-7.

43. Rader DJ. Liver X receptor and farnesoid X receptor as therapeutic targets. Am. J. Cardiol. 2007; 100(11 A):n15-n19.

44. Yu L, York J, von Bergmann K, Lutjohann D, Cohen JC, Hobbs HH. Stimulation of cholesterol excretion by the liver X receptor agonist requires ATP-binding cassette transporters G5 and G8. J. Biol. Chem. 2003; 278(18):15565-70.

45. Plosch T, Bloks VW, Terasawa Y, Berdy S, Siegler K, Van Der SF et al. Sitosterolemia in ABC-transporter G5-deficient mice is aggravated on activation of the liver-X receptor. Gastroenterology 2004; 126(1):290-300.

46. Uppal H, Saini SP, Moschetta A, Mu Y, Zhou J, Gong H et al. Activation of LXRs prevents bile acid toxicity and cholestasis in female mice. Hepatology 2007; 45(2):422-32.

47. Uppal H, Zhai Y, Gangopadhyay A, Khadem S, Ren S, Moser JA et al. Activation of liver X receptor sensitizes mice to gallbladder cholesterol crystallization. Hepatology 2008; 47(4):1331-42.

48. Chiang JY, Kimmel R, Stroup D. Regulation of cholesterol 7alpha-hydroxylase gene (CYP7A1) transcription by the liver orphan receptor (LXRalpha). Gene 2001; 262(1-2):257-65. 
49. Kotokorpi P, Ellis E, Parini P, Nilsson LM, Strom S, Steffensen KR et al. Physiological differences between human and rat primary hepatocytes in response to liver X receptor activation by 3-[3-[N-(2-chloro-3-trifluoromethylbenzyl)-(2,2-diphenylethyl)amino]propyloxy]phe nylacetic acid hydrochloride (GW3965). Mol. Pharmacol. 2007; 72(4):947-55.

50. Schultz JR, Tu H, Luk A, Repa JJ, Medina JC, Li L et al. Role of LXRs in control of lipogenesis. Genes Dev. 2000; 14(22):2831-8.

51. Grefhorst A, Elzinga BM, Voshol PJ, Plosch T, Kok T, Bloks VW et al. Stimulation of lipogenesis by pharmacological activation of the liver X receptor leads to production of large, triglyceride-rich very low density lipoprotein particles. J. Biol. Chem. 2002; 277(37):34182-90.

52. Yoshikawa T, Shimano H, Amemiya-Kudo M, Yahagi N, Hasty AH, Matsuzaka T et al. Identification of liver X receptor-retinoid X receptor as an activator of the sterol regulatory element-binding protein 1c gene promoter. Mol. Cell Biol. 2001; 21(9):2991-3000.

53. Cozzone D, Debard C, Dif N, Ricard N, Disse E, Vouillarmet J et al. Activation of liver X receptors promotes lipid accumulation but does not alter insulin action in human skeletal muscle cells. Diabetologia 2006; 49(5):990-9.

54. Choe SS, Choi AH, Lee JW, Kim KH, Chung JJ, Park J et al. Chronic activation of liver X receptor induces beta-cell apoptosis through hyperactivation of lipogenesis: liver X receptor-mediated lipotoxicity in pancreatic beta-cells. Diabetes 2007; 56(6):1534-43.

55. Repa JJ, Liang G, Ou J, Bashmakov Y, Lobaccaro JM, Shimomura I et al. Regulation of mouse sterol regulatory element-binding protein-1c gene (SREBP-1c) by oxysterol receptors, LXRalpha and LXRbeta. Genes Dev. 2000; 14(22):2819-30.

56. Liang G, Yang J, Horton JD, Hammer RE, Goldstein JL, Brown MS. Diminished hepatic response to fasting/refeeding and liver X receptor agonists in mice with selective deficiency of sterol regulatory element-binding protein-1c. J. Biol. Chem. 2002; 277(11):9520-8.

57. Joseph SB, Laffitte BA, Patel PH, Watson MA, Matsukuma KE, Walczak R et al. Direct and indirect mechanisms for regulation of fatty acid synthase gene expression by liver X receptors. J. Biol. Chem. 2002; 277(13):11019-25.

58. Chu K, Miyazaki M, Man WC, Ntambi JM. Stearoyl-coenzyme A desaturase 1 deficiency protects against hypertriglyceridemia and increases plasma high-density lipoprotein cholesterol induced by liver X receptor activation. Mol. Cell Biol. 2006; 26(18):6786-98.

59. Cha JY, Repa JJ. The liver X receptor (LXR) and hepatic lipogenesis. The carbohydrate-response element-binding protein is a target gene of LXR. J. Biol. Chem. 2007; 282(1):743-51.

60. Zhang Y, Repa JJ, Inoue Y, Hayhurst GP, Gonzalez FJ, Mangelsdorf DJ. Identification of a liver-specific uridine phosphorylase that is regulated by multiple lipidsensing nuclear receptors. Mol. Endocrinol. 2004; 18(4):851-62. 
61. Inaba T, Matsuda M, Shimamura M, Takei N, Terasaka N, Ando Y et al. Angiopoietin-like protein 3 mediates hypertriglyceridemia induced by the liver X receptor. J. Biol. Chem. 2003; 278(24):21344-51.

62. Jakel H, Nowak M, Moitrot E, Dehondt H, Hum DW, Pennacchio LA et al. The liver X receptor ligand T0901317 down-regulates APOA5 gene expression through activation of SREBP-1c. J. Biol. Chem. 2004; 279(44):45462-9.

63. Grefhorst A, van Dijk TH, Hammer A, van der Sluijs FH, Havinga R, Havekes LM et al. Differential effects of pharmacological liver X receptor activation on hepatic and peripheral insulin sensitivity in lean and ob/ob mice. Am. J. Physiol Endocrinol. Metab. 2005; 289(5):E829-E838.

64. Albers M, Blume B, Schlueter T, Wright MB, Kober I, Kremoser C et al. A novel principle for partial agonism of liver X receptor ligands. Competitive recruitment of activators and repressors. J. Biol. Chem. 2006; 281(8):4920-30.

65. Herzog B, Hallberg M, Seth A, Woods A, White R, Parker MG. The nuclear receptor cofactor, receptor-interacting protein 140, is required for the regulation of hepatic lipid and glucose metabolism by liver X receptor. Mol. Endocrinol. 2007; 21(11):2687-97.

66. Janowski BA, Willy PJ, Devi TR, Falck JR, Mangelsdorf DJ. An oxysterol signalling pathway mediated by the nuclear receptor LXR alpha. Nature 1996; 383(6602):728-31.

67. Forman BM, Ruan B, Chen J, Schroepfer GJ, Jr., Evans RM. The orphan nuclear receptor LXRalpha is positively and negatively regulated by distinct products of mevalonate metabolism. Proc. Natl. Acad. Sci. U. S. A. 1997; 94(20):10588-93.

68. Janowski BA, Grogan MJ, Jones SA, Wisely GB, Kliewer SA, Corey EJ et al. Structural requirements of ligands for the oxysterol liver X receptors LXRalpha and LXRbeta. Proc. Natl. Acad. Sci. U. S. A. 1999; 96(1):266-71.

69. Fu X, Menke JG, Chen Y, Zhou G, MacNaul KL, Wright SD et al. 27-hydroxycholesterol is an endogenous ligand for liver X receptor in cholesterol-loaded cells. J. Biol. Chem. 2001; 276(42):38378-87.

70. Quinet EM, Savio DA, Halpern AR, Chen L, Miller CP, Nambi P. Gene-selective modulation by a synthetic oxysterol ligand of the liver X receptor. J. Lipid Res. 2004; 45(10):1929-42.

71. Chen W, Chen G, Head DL, Mangelsdorf DJ, Russell DW. Enzymatic reduction of oxysterols impairs LXR signaling in cultured cells and the livers of mice. Cell Metab. 2007; 5(1):73-9.

72. Song C, Hiipakka RA, Liao S. Selective activation of liver X receptor alpha by 6alpha-hydroxy bile acids and analogs. Steroids 2000; 65(8):423-7.

73. Song C, Liao S. Cholestenoic acid is a naturally occurring ligand for liver X receptor alpha. Endocrinology 2000; 141(11):4180-4. 
74. Lund EG, Peterson LB, Adams AD, Lam MH, Burton CA, Chin J et al. Different roles of liver X receptor alpha and beta in lipid metabolism: effects of an alphaselective and a dual agonist in mice deficient in each subtype. Biochem. Pharmacol. 2006; 71(4):453-63.

75. Quinet EM, Savio DA, Halpern AR, Chen L, Schuster GU, Gustafsson JA et al. Liver X receptor (LXR)-beta regulation in LXRalpha-deficient mice: implications for therapeutic targeting. Mol. Pharmacol. 2006; 70(4):1340-9.

76. Collins JL, Fivush AM, Watson MA, Galardi CM, Lewis MC, Moore LB et al. Identification of a nonsteroidal liver X receptor agonist through parallel array synthesis of tertiary amines. J. Med. Chem. 2002; 45(10):1963-6.

77. Miao B, Zondlo S, Gibbs S, Cromley D, Hosagrahara VP, Kirchgessner TG et al. Raising HDL cholesterol without inducing hepatic steatosis and hypertriglyceridemia by a selective LXR modulator. J. Lipid Res. 2004; 45(8):1410-7.

78. Brunham LR, Kruit JK, Pape TD, Parks JS, Kuipers F, Hayden MR. Tissue-specific induction of intestinal ABCA1 expression with a liver X receptor agonist raises plasma HDL cholesterol levels. Circ. Res. 2006; 99(7):672-4.

79. Sparrow CP, Baffic J, Lam MH, Lund EG, Adams AD, Fu X et al. A potent synthetic LXR agonist is more effective than cholesterol loading at inducing ABCA1 mRNA and stimulating cholesterol efflux. J. Biol. Chem. 2002; 277(12):10021-7.

80. Singh SB, Ondeyka JG, Liu W, Chen S, Chen TS, Li X et al. Discovery and development of dimeric podocarpic acid leads as potent agonists of liver X receptor with HDL cholesterol raising activity in mice and hamsters. Bioorg. Med. Chem. Lett. 2005; 15(11):2824-8.

81. Kher S, Lake K, Sircar I, Pannala M, Bakir F, Zapf J et al. 2-Aryl-N-acyl indole derivatives as liver X receptor (LXR) agonists. Bioorg. Med. Chem. Lett. 2007; 17(16):4442-6

82. Molteni V, Li X, Nabakka J, Liang F, Wityak J, Koder A et al. N-Acylthiadiazolines, a new class of liver X receptor agonists with selectivity for LXRbeta. J. Med. Chem. 2007; 50(17):4255-9.

83. Panday N, Benz J, Blum-Kaelin D, Bourgeaux V, Dehmlow H, Hartman P et al. Synthesis and evaluation of anilinohexafluoroisopropanols as activators/modulators of LXRalpha and beta. Bioorg. Med. Chem. Lett. 2006; 16(19):5231-7.

84. Traves PG, Hortelano S, Zeini M, Chao TH, Lam T, Neuteboom ST et al. Selective activation of liver X receptors by acanthoic acid-related diterpenes. Mol. Pharmacol. 2007; 71(6):1545-53.

85. Szewczyk JW, Huang S, Chin J, Tian J, Mitnaul L, Rosa RL et al. SAR studies: designing potent and selective LXR agonists. Bioorg. Med. Chem. Lett. 2006; 16(11):3055-60. 
86. Tamehiro N, Sato Y, Suzuki T, Hashimoto T, Asakawa Y, Yokoyama S et al. Riccardin C: a natural product that functions as a liver X receptor (LXR)alpha agonist and an LXRbeta antagonist. FEBS Lett. 2005; 579(24):5299-304.

87. Ou J, Tu H, Shan B, Luk A, DeBose-Boyd RA, Bashmakov Y et al. Unsaturated fatty acids inhibit transcription of the sterol regulatory element-binding protein-1c (SREBP-1c) gene by antagonizing ligand-dependent activation of the LXR. Proc. Natl. Acad. Sci. U. S. A. 2001; 98(11):6027-32.

88. Yoshikawa T, Shimano H, Yahagi N, Ide T, Amemiya-Kudo M, Matsuzaka T et al. Polyunsaturated fatty acids suppress sterol regulatory element-binding protein 1c promoter activity by inhibition of liver X receptor (LXR) binding to LXR response elements. J. Biol. Chem. 2002; 277(3):1705-11.

89. Song C, Hiipakka RA, Liao S. Auto-oxidized cholesterol sulfates are antagonistic ligands of liver X receptors: implications for the development and treatment of atherosclerosis. Steroids 2001; 66(6):473-9.

90. Kim KH, Choi SH, Lee TS, Oh WK, Kim DS, Kim JB. Selective LXRalpha inhibitory effects observed in plant extracts of MEH184 (Parthenocissua tricuspidata) and MEH185 (Euscaphis japonica). Biochem. Biophys. Res. Commun. 2006; 349(2):513-8.

91. Tangirala RK, Bischoff ED, Joseph SB, Wagner BL, Walczak R, Laffitte BA et al. Identification of macrophage liver X receptors as inhibitors of atherosclerosis. Proc. Natl. Acad. Sci. U. S. A. 2002; 99(18):11896-901.

92. Levin N, Bischoff ED, Daige CL, Thomas D, Vu CT, Heyman RA et al. Macrophage liver X receptor is required for antiatherogenic activity of LXR agonists. Arterioscler. Thromb. Vasc. Biol. 2005; 25(1):135-42.

93. Bradley MN, Hong C, Chen M, Joseph SB, Wilpitz DC, Wang X et al. Ligand activation of LXR beta reverses atherosclerosis and cellular cholesterol overload in mice lacking LXR alpha and apoE. J. Clin. Invest. 2007; 117(8):2337-46.

94. Castrillo A, Joseph SB, Marathe C, Mangelsdorf DJ, Tontonoz P. Liver X receptor-dependent repression of matrix metalloproteinase-9 expression in macrophages. J. Biol. Chem. 2003; 278(12):10443-9.

95. Terasaka N, Hiroshima A, Ariga A, Honzumi S, Koieyama T, Inaba T et al. Liver X receptor agonists inhibit tissue factor expression in macrophages. FEBS J. 2005; 272(6):1546-56.

96. Ogawa D, Stone JF, Takata Y, Blaschke F, Chu VH, Towler DA et al. Liver x receptor agonists inhibit cytokine-induced osteopontin expression in macrophages through interference with activator protein-1 signaling pathways. Circ. Res. 2005; 96(7):e59-e67.

97. Fontaine C, Rigamonti E, Nohara A, Gervois P, Teissier E, Fruchart JC et al. Liver X receptor activation potentiates the lipopolysaccharide response in human macrophages. Circ. Res. 2007; 101(1):40-9. 
98. Arai S, Shelton JM, Chen M, Bradley MN, Castrillo A, Bookout AL et al. A role for the apoptosis inhibitory factor AIM/Spalpha/Api6 in atherosclerosis development. Cell Metab. 2005; 1(3):201-13.

99. Valledor AF, Hsu LC, Ogawa S, Sawka-Verhelle D, Karin M, Glass CK. Activation of liver X receptors and retinoid X receptors prevents bacterial-induced macrophage apoptosis. Proc. Natl. Acad. Sci. U. S. A. 2004; 101(51):17813-8. 
Figure legends

\section{Figure 1 : Role of LXR in cholesterol homeostasis}

LXR play an important role in controlling cholesterol homeostasis via coordinated effects on intestinal cholesterol absorption by up-regulation of ABCG5 and ABCG8 and down-regulation of NPC1L1, on reverse cholesterol transport via a direct action on genes involved in the maturation of HDL (ABCA1, ABCG1) in macrophages and upregulation of genes implicated in HDL remodelling (apo E, PLTP, LPL, CETP), and finally on cholesterol excretion from liver by enhancing its elimination into bile through activation of the Cyp7A1 gene expression.

\section{Figure 2 : Role of LXR in triglyceride metabolism}

Upon activation, LXR up-regulates $(\uparrow)$ expression of hepatic genes involved in fatty acid biosynthesis (SREBP1c, FAS, ACC, SCD1, ChREBP, and possibly L-UrdPase) and down-regulates $(\downarrow)$ genes involved in triglyceride metabolism (Angptl1, apoA-V), leading therefore to hepatic steatosis and hypertriglyceridemia. 


\section{Abbreviations :}

LXR : Liver X Receptor

ABC : ATP-binding cassette transporter

NPC1L1 : Niemann-Pick C1 like 1

LDLR : LDL receptor

SREBP : sterol regulatory element-binding protein

SQS : squalene synthase

RCT : reverse cholesterol transport

HDL : high-density lipoproteins

Apo : apolipoprotein

PLTP : phospholipids transfer protein

CETP : cholesteryl ester transfer protein

LPL : lipoprotein lipase

SCD1 : stearoyl-coenzyme A desaturase

FAS : fatty acid synthase

ACC : acetyl-coA carboxylase

ChREBP : carbohydrtae response element binding protein

Angptl3 : angiopoietin-like protein 3

SLXRM : selective LXR modulator

$\mathrm{RC}$ : riccardin

AIM : apoptosis inhibitory factor 
Table : Differential effects of LXR activation by T0901317 and GW 3965 treatment on lipid metabolism in mice

\begin{tabular}{|c|c|c|c|c|c|c|}
\hline Agonist & $\begin{array}{c}\text { Targeted isoform } \\
\text { selectivity }\end{array}$ & Mouse model & $\begin{array}{l}\text { Tissue selectivity } \\
\text { (liver / intestine) }\end{array}$ & $\begin{array}{l}\text { Cholesterol } \\
\text { metabolism }\end{array}$ & $\begin{array}{c}\text { Fatty acid } \\
\text { metabolism }\end{array}$ & References \\
\hline Т0901317 & $\operatorname{LXR} \alpha>\operatorname{LXR} \beta$ & $\begin{array}{l}\text { C57BL6 } \\
\text { C57BL6 } \\
\text { C57BL6 } \\
\text { LDLR-deficient } \\
\text { LDLR-deficient }\end{array}$ & $\begin{array}{l}\uparrow \text { CYP7A1 (liver) } \\
\downarrow \text { SQS, HMCoAS (liver) } \\
\uparrow \text { ACC, FAS (liver) } \\
\uparrow \text { SREBP-1c, SCD1 (intestine, liver) } \\
\\
\uparrow \text { ABCA1 (liver, intestine) } \\
\uparrow \text { FAS, SREBP-1c, (liver) } \\
\uparrow \text { ABCA1, ABCG1, CYP7A1, } \\
\text { SREBP-1c, FAS, ACC (liver) } \\
\uparrow \text { ABCA1, SREBP-1c (intestine) } \\
\\
\\
\\
\uparrow \text { ABCA1 (liver) } \\
\uparrow \text { SREBP-1c, FAS, ACC (liver) } \\
\uparrow \text { ABCA1, ABCG5, ABCG8 (intestine) }\end{array}$ & $\begin{aligned} & \uparrow \text { HDL-C } \\
& \\
& \uparrow \mathrm{TC}, \text { HDL-C } \\
& \uparrow \mathrm{TC}, \mathrm{VLDL}-\mathrm{C}, \\
& \text { LDL-C, HDL-C } \\
= & \mathrm{TC} \\
\downarrow & \downarrow \text { (VLDL+LDL)-C } \\
\uparrow & \text { HDL-C } \\
& \uparrow \mathrm{VLDL}-\mathrm{C} \\
& \downarrow \text { LDL-C, HDL-C }\end{aligned}$ & $\begin{array}{l}\uparrow \text { TG, VLDL } \\
\uparrow \text { hepatic TG } \\
=\text { TG } \\
\uparrow \text { hepatic TG } \\
\uparrow \text { TG } \\
\uparrow \text { TG (transiently) } \\
\uparrow \text { TG, VLDL-TG, } \\
\text { LDL-TG } \\
\uparrow \text { hepatic TG }\end{array}$ & $\begin{array}{l}{[77]} \\
{[70]} \\
{[15]} \\
{[13]}\end{array}$ \\
\hline GW3965 & LXR $\alpha$, LXR $\beta$ (weak) & $\begin{array}{l}\text { C57BL6 } \\
\text { Apo E-deficient } \\
\text { LDLR-deficient } \\
\text { Intestinal } \\
\text { ABCAI-deficient }\end{array}$ & $\begin{array}{l}=\mathrm{ABCA} 1 \text { (liver) } \\
=\mathrm{FAS}, \mathrm{SREBP}-1 \mathrm{c} \text { (liver) } \\
\uparrow \mathrm{ABCA1} \text { (intestine) } \\
\uparrow \mathrm{CYP7A1} \text { (liver) } \\
=\mathrm{ABCA} \text { 1, ABCG1 (liver) } \\
\uparrow \mathrm{ABCA1} \text {, ABCG1 (intestine) } \\
\\
=\mathrm{ABCA1} \text { (liver) } \\
\uparrow \mathrm{ABCG}, \text { ABCG1, SREBP-1c }\end{array}$ & $\begin{array}{l}=\mathrm{TC} \\
\uparrow \mathrm{HDL}-\mathrm{C} \\
=\mathrm{TC}, \mathrm{HDL}-\mathrm{C} \\
\downarrow \mathrm{TC} \\
=\mathrm{HDL}-\mathrm{C} \\
=\mathrm{TC}, \mathrm{HDL}-\mathrm{C}\end{array}$ & $\begin{array}{l}=\mathrm{TG} \\
=\text { hepatic } \mathrm{TG} \\
\uparrow \mathrm{TG} \\
=\mathrm{TG} \\
=\mathrm{TG}\end{array}$ & $\begin{array}{l}{[11]} \\
{[78]}\end{array}$ \\
\hline
\end{tabular}




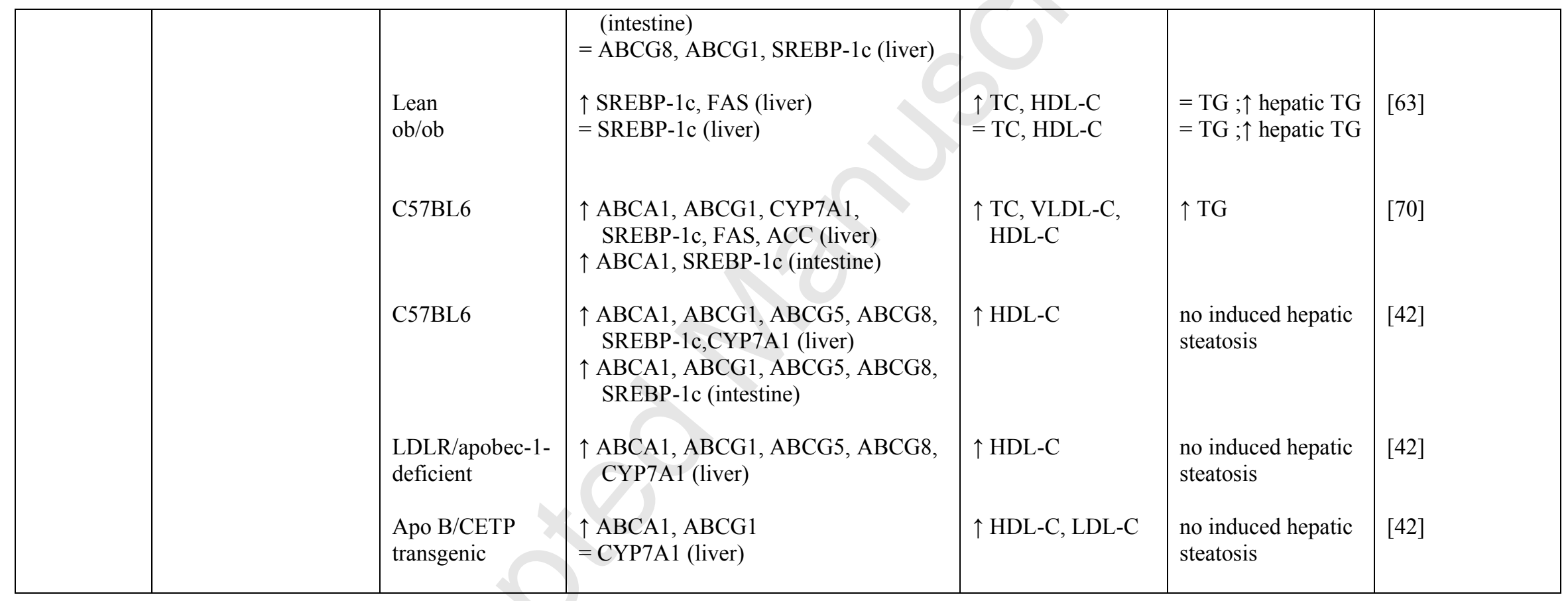

Abbreviations : TC : cholesterol total ; TG : triglycerides ; HDL-C : high-density lipoprotein cholesterol ; LDL-C : low-density lipoprotein cholesterol ;

VLDL-C : very low-density-lipoprotein cholesterol ; $\uparrow$ increased following treatment ; $\downarrow$ decreased following treatment ; = unchanged following treatment 


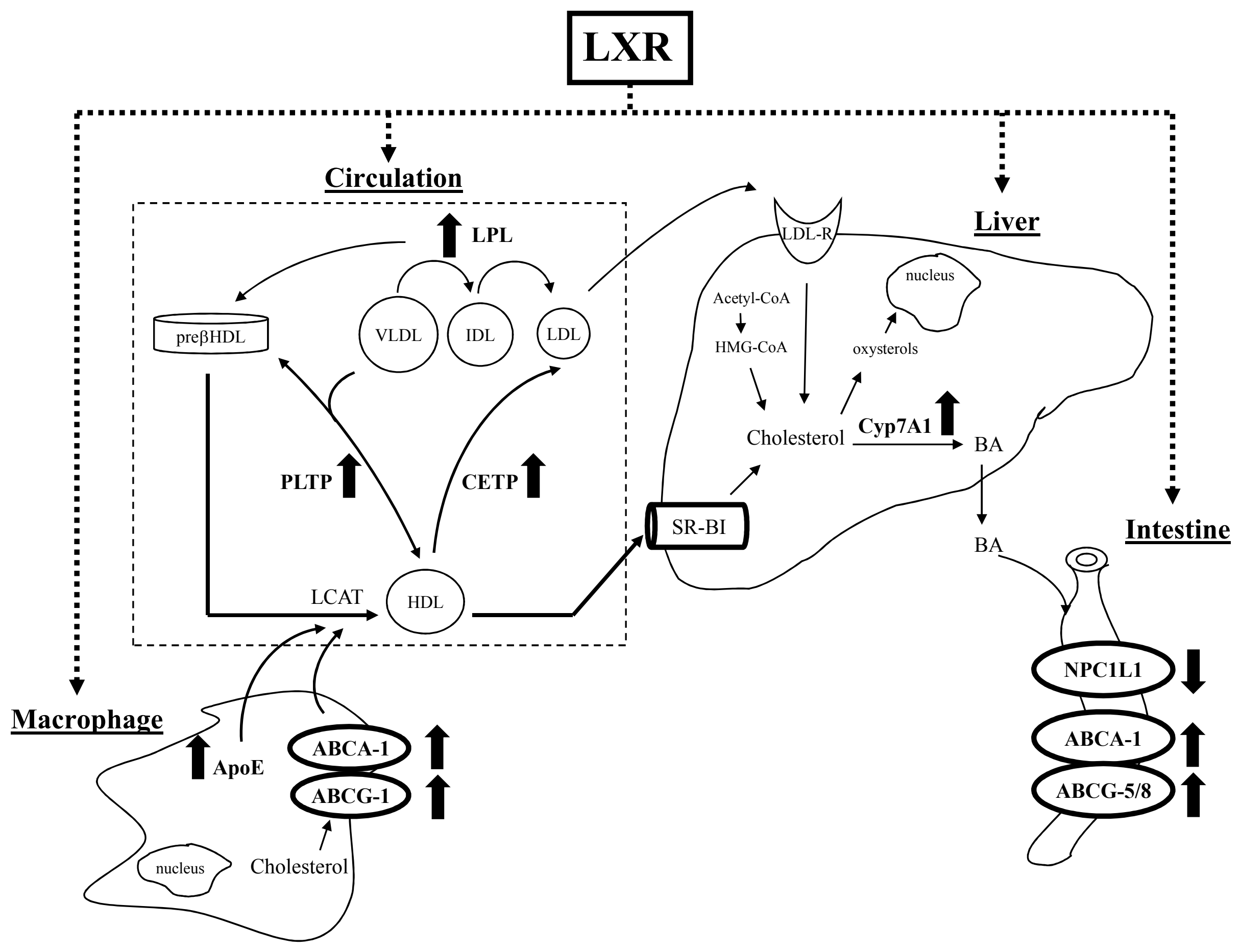




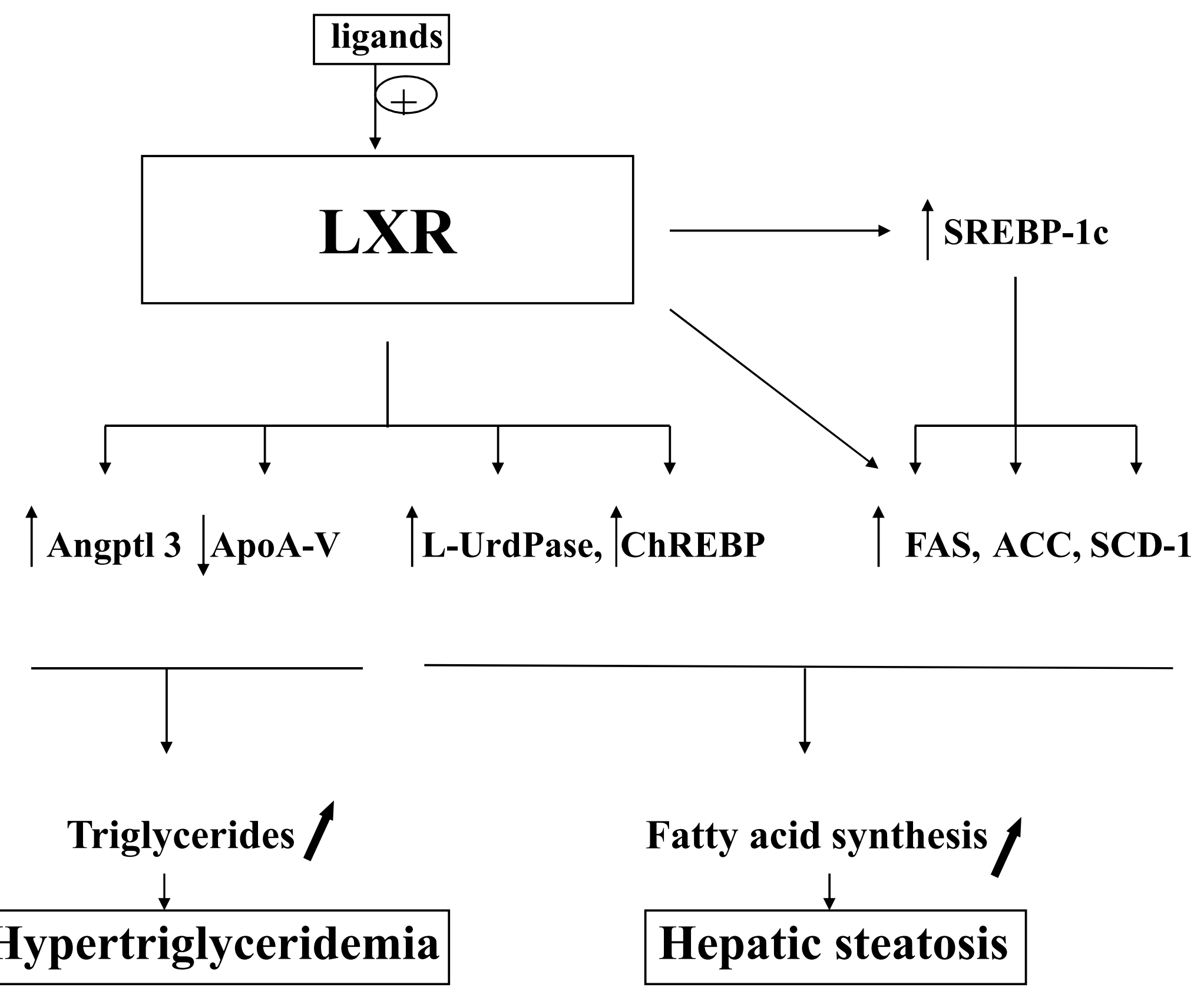

